\title{
LIST OF ABBREVIATIONS
}

$\begin{array}{ll}\text { APHA } & \text { American Public Health Association } \\ \text { APHIS } & \text { Animal and Plant Health Inspection Service (of USDA) } \\ \text { BGH } & \text { Bovine growth hormone (see bST) } \\ \text { BIO } & \text { Biotechnology Industry Organization } \\ \text { BSE } & \text { Bovine spongiform encephalopathy (mad cow disease) } \\ \text { bST } & \text { Bovine somatotropin (see BGH) } \\ \text { Bt } & \text { Bacillus thuringiensis } \\ \text { CDC } & \text { Centers for Disease Control and Prevention (of DHHS) } \\ \text { CFSAN } & \text { Center for Food Safety and Applied Nutrition (of FDA) } \\ \text { CJD } & \text { Creutzfeldt-Jakob Disease } \\ \text { CNI } & \text { Community Nutrition Institute } \\ \text { CSPI } & \text { Center for Science in the Public Interest } \\ \text { DHHS } & \text { U.S. Department of Health and Human Services } \\ \text { DNA } & \text { Deoxyribonucleic acid } \\ \text { EC } & \text { European Commission (of the EU) } \\ \text { EMS } & \text { Eosinophilia-Myalgia Syndrome } \\ \text { EPA } & \text { Environmental Protection Agency } \\ \text { ERS } & \text { Economic Research Service (of USDA) } \\ \text { EU } & \text { European Union } \\ \text { FDA } & \text { Food and Drug Administration (of DHHS) } \\ \text { FIFRA } & \text { Federal Insecticide, Fungicide and Rodenticide Act of } \\ & \text { I988 } \\ \text { FSIS } & \text { Food Safety and Inspection Service (of USDA) }\end{array}$

Additional abbreviations are defined in the Notes. 


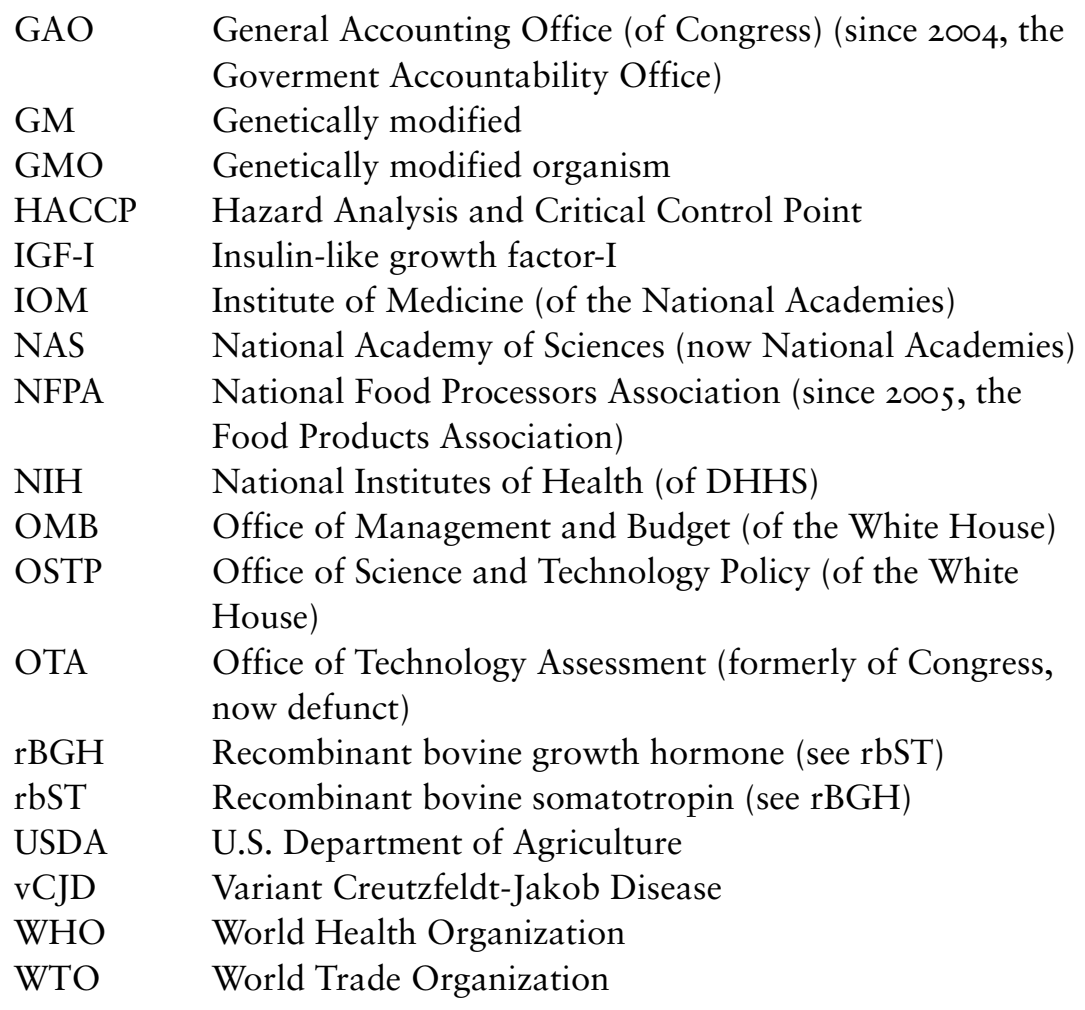

